9

\title{
Protestant place, Protestant props in the plays of Nicholas Grimald
}

\section{Elisabeth Dutton}

Early in the English Reformation the churchman, historian, controversialist, and Protestant convert John Bale (1495-1563), recognising the evangelical potential of theatre, set about harnessing it to the Protestant cause. His work is concerned not just with the ideas that might be presented in a Reforming play, but also with the manner in which a Protestant play sets up those ideas for performance, through material objects in time and space. In this chapter I will explore some of the ways that Reforming playwrights deploy these realities theatrically; in other words, considering 'objects' as props, and 'time and space' as the duration of the play and the space of its performance, I will explore how these dramaturgical phenomena are deployed by Reforming playwrights to present an argument about the same phenomena in the world beyond the play as understood in Protestant theology. I will focus on Bale and his friend the poet and dramatist Nicholas Grimald (1519-62), whose Protestant playwriting took place while he was a student at Oxford. Two of Grimald's plays survive: the Latin scriptural dramas Christus Redivivus, a Resurrection narrative that was performed at Brasenose College in 1541, and Archipropheta, the John the Baptist story, that was staged at Christ Church in $1548 .{ }^{1}$ I will also allude to Andreas Höfele's study of the comedy Christus Triumphans, by another of Bale's friends, the historian and martyrologist John Foxe (1516/17-87): Foxe's play was performed at Magdalen College, Oxford in 1561-62, and Bale's Three Laws may also have been performed at Magdalen around the same time. ${ }^{2}$

Protestant writers sought to demonstrate that they were the true heirs of the early Church, revealing it in its first, pure, state, while also demonstrating that contemporary corrupt Catholic practices were both survivals of superseded Jewish practice from before the time of Christ and signs of the approaching end times. What came before, what happens now, and what comes next are all contested: Protestant drama may be deeply engaged with the pressing questions 
of its age, but in order to sustain this, it must embrace a decidedly confusing sense of time. In his Three Laws, John Bale (1538-89) chooses to portray on stage the whole of human history divided by period - the time of Natural Law, the time of the Law of Moses, and the time of the Law of Christ. ${ }^{3}$ Christ's Law represents the written Bible, itself a continuation and confirmation of the purity of natural teaching; the Scriptures taken as a whole are seen to subsume the role of Moses within them. So time in Bale's play is more complicated than simply one age succeeding another. The first scene shows all of the laws together, outside time and place. Moreover, while the majority of the action is apparently set in the past, the temporal differences are always elided - through both reference and dramaturgy - so that the play is actually understood to be referring to contemporary, Reformation England. ${ }^{4}$

A play, at least if it is written to be staged, must pay attention to the practicalities of chronology and geography: an actor's body must occupy a time and space. When Deus Pater tells Naturae Lex that he must rule for 'three ages', from Adam to Noah, from Noah to Abraham, and from Abraham to Moses, Naturae Lex is puzzled: 'Where must I remayne, for the tyme I shall be here?' The reply, 'In the hart of man', may not appear the most helpful direction for the mise-en-scène. Similarly, when given their commissions, the Laws of Moses and Christ also ask, 'Where shall I for that same season dwell?', 'Where shall I for that same time persever?' ${ }^{5}$ Neither God the Father, nor Bale, offers any clue as to how these questions should be resolved on the stage. Yet Bale's strategy, making the question part of the play, both contains the issues and foregrounds one of the difficulties of Protestant drama. ${ }^{6}$

The Catholic mystery plays also present scripture while making their points about contemporary society, deploying creative anachronism in their costumes, oath, and references to social office; however, their overarching trajectory is always clear. The Protestant playwrights were presented with a particularly difficult temporal project because they had arguments to make about their Reformed practices in relation to the history of the Church, which inevitably involved them in telling history from a human perspective, while at the same time they sought to appropriate the 'papist' dramatic project of the mystery cycles - presenting soteriological time. Andreas Höfele writes of John Foxe's Christus Triumphans (1556):

Whereas the mystery cycles string out their episodes 'from eternity to eternity' in linear sequence, beginning with the Creation and ending 
with the Last Judgment, Foxe must supplement and synchronize this biblical chronology with a second narrative strand, the history of the Church from the days of the Apostles to the present. He thus has more to tell than the mystery cycles but much less time in which to tell it; for while the mysteries took a whole day or two (or even weeks as in France) to unfold their story, Foxe was constrained by the limits imposed by the five acts of a Latin comedy. ${ }^{7}$

Foxe's answer to the five-act constraints is, as Höfele puts it, 'radical conflation'. ${ }^{2}$ This conflation is temporal - as when, for example, Eve meets Mary on Easter Saturday - and also in a sense spatial, since Satan laments that he has become a homeless exile (Extorris e coelo eliminor, ubi / Loci nihil est reliquum, 'Exiled, banished from heaven, where there is no place left', ${ }^{9}$ I.iii.6-7), although he already has his residence in the underworld. The most striking moment of spatial manipulation is in Act V, when Satan, with his devils, visits his deputy the Pope - in Rome, one would imagine. Yet instead, when the papal Antichrist asks for directions to help him find the heretic Hierologus, we find that we are in Oxford:

Ad forum cum acceditis escarium,

Quadriuium illic est, transuersis plateis sese in angulos

Rectos scindens. Hic relicta dextra, ad laeuam uergite ...

Versus utramque ursam. Illic secum portam

... carcer Bocardo est. Ibi est. (V.ii.19-31) ${ }^{10}$

(As you approach the Cornmarket, you come to Carfax, where the intersecting streets go off at right angles. Ignore the right and turn left ... towards the two Bears. There, beside the gate ... is the prison, Bocardo. He's there.)

At the time of Foxe's writing the Bocardo prison counted Thomas Cranmer among its inmates; earlier it had also counted Latimer and Ridley. Clearly, the 'heretics' are these three men, the Oxford Martyrs, in the most pointed of contemporary references, before the play returns to its abstract apocalyptic war between Antichrist and Ecclesia.

Time presents a further challenge to John Foxe: the Apocalypse, which will conclude his play's action, has not yet come, and so Foxe can only end his play with a Chorus of Virgins who seem to be like the Wise Virgins of the parable, waiting with their oil lamps ready for the coming of the bridegroom:

Paratum nunc sponsam, spectatores, cuncta ac

Parata cernitis. Restat nihil, ipse 
Nisi paranymphus summam qui scenae imponat

Catastrophen. Id quum fiet certum nemo

Dicet. Poeta, quod possit, praestitit. (V.v.150-4)

(Spectators, now you see the bride decked out and all things in readiness. Nothing remains except the bridegroom himself, who will bring the final catastophe to our stage. When that will happen none will say for sure. The poet has shown what he could.)

The author's self-effacing phrase is interesting - that he has shown 'what he could' might imply a lack of skill or a lack of knowledge, although here it is in a way also a lack of material, since he wishes to write truly about something that has not yet happened. In any case, the result is that Foxe resigns his authorial responsibility and instead hands responsibility to the audience, who must wait prepared, must 'be on your guard with prudence' - and incidentally, 'et plaudite' ('do clap, please!', V.v.163). A satisfying connection being thus drawn between watching eagerly for the bridegroom Christ and watching receptively the present play, Foxe is able to put his pen down and enjoy the applause that concludes a play that is by definition unfinished in the present (which is to say, 1556). ${ }^{11}$

Of course, conflations of time and space are a marked feature of medieval drama, both secular and scriptural, too: the York Cycle, performed in the streets of York, both draws attention to the real streets and simultaneously transforms them into the streets of Jerusalem; in Fulgens and Lucres the dining hall in which the play is presented is sometimes just a dining hall, here and now, and sometimes Ancient Rome. ${ }^{12}$ But those are logical enough bi-locations; Foxe is doing something different. His audience veers exhilaratingly from Old Testament Jerusalem, to Rome, Oxford, Hell, the time of Christ, the history of the early Church, and the English Reformation. Foxe writes a five-act Latin comedy, but it is far from observing the unities of place, time, and action that might be expected in Latin comedy following dictates about dramatic structure derived from Aristotle's Poetics. Unless, perhaps, we can think of 'all places' and 'all times' as unities of a sort. Possibly, by never solidly establishing a single setting, Foxe enables his audience to ignore the implausibility of the sudden scene-shifts: possibly his dramaturgy frees the audience from thinking literally.

Grimald's classical imitations include dramatic form and tropes - the five acts, the commentary of a Chorus, demons from the underworld, characters such as the cunning slave and the braggard 
soldier - as well as literary language: the Latin of these plays is classical Latin, and they often involve echoes of phrases, paraphrases, and extensive citation also from non-dramatic sources such as Virgil's Aeneid and Horace's Odes. ${ }^{13}$ For Grimald, the genres of classical drama also offered some way of avoiding the temporal perils besetting Foxe and Bale: it is clear that, when the protagonist is dead, the tragedy is complete. Thus Archipropheta finishes with the Chorus lamenting the death of John the Baptist. It is clear that when the confusions are resolved, the comedy is done. Thus Christus Redivivus finishes when Thomas has been brought from scepticism to belief.

Grimald is also perhaps less concerned than Bale and Foxe to comment on the England of his age, although even the writing of a play about John the Baptist in 1547 may not have been an entirely innocent act, given the near-contemporary plays by prominent Protestants John Bale and George Buchanan on the same theme. ${ }^{14}$ Yet Grimald does not write a Latin or a medieval comedy. His plays look forward, of course, but with less contemporary weight: the risen Christ promises his listeners that if they wait a little while, they will receive the Holy Ghost, but His words echo Christ's promise of Pentecost, and that is done. The Epilogue to Christus Redivivus is happy to assert that they are finished: Habetis rem totam, auditores optimi ('Most worthy listeners, you have the whole play', pp. 214-15). Archipropheta could not be more emphatic about its conclusion, which is the grave: Sepulchrum sic possum, sic autum funus est. Voce supremum ciemus iam: Vale, uale ('Thus his grave is made, thus his burial is finished. Now let us raise our last cry, Farewell! farewell!', pp. 356-7).

Grimald's plays loosely observe the classical requirement for unity of place. In the dedicatory epistle to Christus Redivivus, Grimald writes that his teacher praises the propriety of his classical style and form, and that Loca item, haud usque eo discriminari censebat: quin unum in proscenium, facile E citra negocium conduci queant ('Likewise, he concluded that the scenes were not so far apart but they could easily, and without trouble, be reduced to one stagesetting', pp. 108-9). In fact, although most of the action of Christus Redivivus occurs in the garden in which is Christ's tomb, there are some hints of other locations: for example, the Marys narrate to the disciples what they saw in the garden 'when we came there', not 'here'; Thomas declares that a spirit has entered hanc domum ('this house', pp. 198-9), in accordance with scriptural narrative that shows Doubting Thomas encountering the Risen Christ in a locked room. The term is richly suggestive in academic drama: as 
'Tiffany Stern has explored, 'house' is a term commonly used in commercial theatre to refer to locations with specific functions playhouse, tiring-house - and those functions included storage of valuable items like costumes and props. ${ }^{15}$ In Oxford, the term was used of a college's hospitality - to be a domus ('guest') is to eat at the college's expense. Thus the Risen Christ visits Thomas in his college, and in a play; for a brief moment the setting and the venue are one and the same. Most strikingly, the diabolical Cacodemon, and the Fury Alecto whom he sends to earth, dwell In haec loca tetra, horrenda, subterranea, / Terribilis, foeda, sent situ E squalida ('in these realms beneath the earth, terrible, unclean, and foul with mouldering filth', pp. 180-3). So there are also scenes that are located in Hell, and Hell is specifically below the earth. If there was indeed only one stage-setting, then it would either have to include a subterranean Hell, or it would have to assume that for these brief scenes the audience were happy to imagine Hell. Perhaps Hell was even among the audience, or behind them: in any case, it is created for the audience by the words of the demons that invoke people and places both scriptural and classical - Orcus, Tartarus, Acheron (p. 180), the garden of Paradise and the Stygian lake (p. 182), and lost Judas (p. 184).

Archipropheta takes place almost entirely at the palace of Herod. Though John and his disciples are initially somewhere in the wilderness, this is defined principally by not being Herod's court (since the king must send people to find John), as well as by John's statement: Mouetur nunc viri mens nostra, saltibus ut / Relictis, deinde gressus per medias feram / Urbes ('my soul prompts me to leave the wilderness and make my way into the midst of cities', pp. 242-3). This statement is as geographically vague as it is symbolically, even soteriologically, loaded: the significance of the city in Christian thought was suggested by references, particularly in the Psalms, to the city of Jerusalem as the place where the tribes praise God (Psalm 122:4), in the book of the prophet Ezekiel that foretells the rebuilt Third Temple in Jerusalem (Ezekiel 45:6), and in the book of Revelation 21 to a 'new Jerusalem' that is Heaven on earth. The significance of this city was cemented by Augustine's De civitate $d e i$, which itself drew on St Paul's comment in the letter to the Hebrews: 'here we have no continuing city, but we seek one to come' (Hebrews 13:14). ${ }^{16}$ Augustine portrays human history as the conflict between the Earthly City and the City of God. ${ }^{17}$ In Grimald's play, therefore, wilderness and city seem almost to be ideas as much as places: there is no effort to create a sense of their topography, 
or their material reality, and the movement from one to the other in John's mind seems somehow to imply the movement from one to the other of John's body. John tells the audience that his soul prompts him to go to the city, and without witnessing any journey the audience understands that he has done so.

Grimald gives no stage directions, no indications of scene; he creates a sense of scripture through references to the Tishbite prophet, or Naaman the Syrian washed in the Jordan (pp. 242-3), to Pharisees and Levites, to Choruses of Idumaeans: it is as if by these references, demonstrating his intimate knowledge of the Gospels and also of Josephus, he makes 'scripture' a time and place all its own, in which the characters of Archipropheta can live and move. So similarly in Christus Redivivus the time-and-place 'scripture' is evoked through moments in which Christ's miracles and teachings are narrated: on the way to the tomb Cleophis narrates the miracle of the wine at the wedding in Cana; Nicodemus recalls his furtive, night-time conversations with Christ; Mary Magdalene tells at length of the woman who was cured of bleeding when she touched Christ's robes. These moments seem qualitatively different from those in the mystery plays, when actors offer brief reminders of action that has happened in earlier pageants: those serve mnemonic functions, but here the narratives seem to build a set, to create Christ's Incarnation and ministry as a time and place to themselves. They are concerned with memory, but their aim is not an audience aidemémoire: Cleophis emphasises that she is recalling the time of miracles from her own earliest memories - Etenim memoria repetebam ultima Tempus ('and indeed I was recalling the time from my earliest memories', pp. 152-3) - not from what the audience has seen performed, and the audience perceives that time as a setting for the actions they witness, as a setting that is carried in the hearts and minds of the disciples, and, with dramatic irony, as a time that the audience but not yet the characters know is not complete in the scriptural setting of the play, for the greatest miracle, Christ's resurrection, has not yet been revealed by the action.

This is in a way the opposite of the mystery plays' drive to bring scripture into the here and now. Protestant writers were presumably concerned to assert the historicity of scriptural events, and to separate them from the debased Catholic forms in which they were commemorated, but this may present a difficulty, since drama that asserts immanence, that its action occupies the audience's time and place, is more immediately appealing than drama that insists that its action represents what actually happened, but in a remote time and place. 
Furthermore, theatre is the most material of arts, and Protestant playwrights needed somehow to make their theology of scriptural time and place, and eschatological history, nonetheless materially present to an audience in their own historical moment. As a result, they had to develop a particular dramaturgy of the material object, the theatrical prop. Andrew Sofer writes that at times of 'semiotic crisis' (such as the Reformation) the prop is a vital dramaturgical tool for 'shaping dramatic and theatrical signification': playwrights concerned that they could not 'legislate' a 'prop's impact' sought particularly to 'orchestrate the prop's movement through concrete stage space and linear stage time' ${ }^{18}$ Objects exist in time and space, obstinately so. Much though stage managers the world over might wish that props could be moved by the imagination, they hang around, sometimes accruing significance, sometimes gradually ignored, but still there. ${ }^{19}$ Their physical reality makes them accessible, but they have no spiritual reality: this of course was the argument of the Protestant iconoclasts.

Scholarly thinking about props in early English drama has often focused, unsurprisingly, on the Eucharistic host. The theatricality of the Mass has been the object of discussion at least since Honorius Augustodunensis, in the twelfth century, made an analogy between the liturgical celebrant and an actor taking on the role of Christ: in the twentieth century O. B. Hardison went so far as to argue that in liturgy were the origins of English drama, though scholars, notably Lawrence Clopper, have argued firmly against this aspect of Hardison's work. ${ }^{20}$ Discussion is dogged, as Bruce Holsinger points out, by an 'all-or-nothing' approach: liturgy is claimed to either be the only real source and substance of all drama or fundamental to none of it. ${ }^{21}$ Thinking very particularly about the bread and wine of the Mass, Sofer considers differing theological positions on the phenomenology of the Mass that can offer 'distinct models for understanding how objects become signs on stage without effacing their material being': the Catholic doctrine of transubstantiation; the Lutheran doctrine of consubstantiation in which the host is both bread and flesh; and the $Z$ winglian doctrine that the bread and wine simply recall Christ's body and blood and there is no 'real presence'. ${ }^{22}$ I will not here focus on the Mass, but I follow Sofer in considering the 'theological' significance of the material being of props: how did Protestant playwrights engage with that materiality?

Bale's Three Laws is not really a scriptural play, in that its narrative is not one found written in the Bible; rather it is a sort of biblical apparatus, presenting as it were the section headings under which 
the whole history of salvation could be arranged. It is clearly the result of Bale thinking with great sophistication about what Protestant drama should do. He focuses considerable attention on props, explored as true and false symbols. Each of the vice figures who come in turn to corrupt the Laws brings with him a selection of religious objects - rosaries, candlesticks, images of angels, and so on. Bale does not explicitly state that these props are brought on stage, but given the uneven nature of medieval and early modern stage directions, this is not surprising: since the vices try to sell their wares, they are presumably carrying them. For example, Idolatria attempts to beguile his audience with an abundance of tricks and trinkets:

Both brouches, beades and pynnes,

With soch as the people wynnes

Unto ydolatrye

Take thu part of them here, Ad Idol. (658-63)

Idololatria's faith is focused upon visible observance of Catholic ritual. Brooches, beads, and pins are nothing but props, but Infidelitas peddles them as idols. Catholicism is exposed in this play as a series of accretions, entirely unauthorised by the biblical source of God's law. Evangelium foregrounds the issue of outward signs and inward significance: 'Their worsyppynges are in outwarde ceremonyes' (1348).

Yet Deus Pater also gives props to the Laws: he gives the New Testament to Christ's Law, and tablets of stone to Moses' Law, and tells them that they are signs and tokens. At the same time, they are also props - objects given to actors - and the actors must do something with them. Moses' Law is apparently expected to stagger around under the weight of two large stones for much of the rest of the play. The Law of Nature has the strangest problem, as he is given a heart - and he apparently does carry it around, as it prompts Infidelity to mistake him for a cook. The very weirdness of these props makes them egregiously dramatic - defamiliarised, perhaps - so that they cannot be corrupted through their interpretations as anything other than signs. In addition to this strategy of staging the bizarre, Bale deploys elemental props - fire and water - as true symbols that contrast with the painted icons of Catholic corruption: Vindicta Dei tells Infidelitas that he will punish him 'with water ... and with fyre' (1824) and the stage directions confirm that he lympha percutit ('throws water', at 1860) on Infidelitas before ignis flamma ('the flame of the fire', at 1893) scares the Vice away. That 
the elements are material but 'true' symbols is connected to their lively materiality: they cannot be contained, packaged, and sold.

So perhaps one answer to the issue of props in relation to iconoclasm is the use of explicitly 'empty' props; non-solid props, or incongruous props, or props that cannot quite be managed by the actors who must work with them. Foxe concludes his Christus Triumphans with the only stage direction in his play to mention props:

Hic ex editori theatri loco, repansis cortinis ostendunt se uelut e coelo sedilia et libri positi (V.v.37-46)

(Here from the upper part of the theatre, when the curtains open, are shown as if from heaven thrones with books placed upon them)

Books, it is true, are objects, but they are perhaps the most complex and suggestive props since their significance depends on what is inside them, and this is usually inaccessible to the audience: a book must be read, and as a prop the book therefore might lead the audience to consider a passage of time beyond that of the performance, in which the book is regarded, page by page, in order for its full significance to be appreciated. Within the time of the performance, of course, the audience may recall a book that they have read, but they cannot read a book: thus, the book is able 'to image one thing and disclose another, to offer words or signs beyond the visible requisites of its presence'. ${ }^{23}$ Thrones too are very material, but their significance is related to the authority of the person seated in them, and these thrones are empty. The scene which Foxe creates clearly recalls the hetoimasia, the 'prepared throne' which was made ready for Christ at his Second Coming and thus came to symbolise the Second Coming: the image, which is common in early Christian art, may have drawn also on the Roman iconography of a judge's seat. ${ }^{24}$ The presence of a book on the throne would usually indicate that the image as a whole represents Christ, but that the thrones are plural complicates the interpretation of Foxe's theatrical image. Perhaps there are four, and each book represents a Gospel, though it is odd that Foxe does not specify the number if this is the case. As Höfele writes, this stage direction 'serves the purpose of allegory rather than localization'; ${ }^{25}$ arguably, however, the nature of allegory is to give a local habitation and a name, because it localises the abstract in the material object, whether prop, or actor's body. A company staging Foxe's play would have to decide on the number of thrones and books it would present, and in the localising process 
of engaging with this material reality would have to interpret the allegory for themselves, guiding also the interpretation of the audience.

Grimald offers his audience an empty tomb and a severed head. 'The 'Argument' of Act I of Christus Redivivus declares, Christus in eo iacet sepulchro conditus ('Christ lies buried in that sepulchre', pp. 116-17). This establishes the presence of the tomb on the stage, but also what is hidden inside it. Mary Magdalene enters, complaining against the unjust Jews, and indicates the Sepulchre: Haec cine tecta? hasce sedes? hosce constituisti toros? ('Is this the dwelling, this the abode, this the couch thou didst prepare?', pp. 120-1). She then embraces the stone that, she asserts, covers Christ - presumably the stone covering the entrance to the tomb - and prays that Christ may quiescas hic molliter ('rest here gently', pp. 120-1). So far, the tomb could be represented by a Hell's-mouth prop, appropriated, with a profound irony. But in the next scene, Joseph of Arimathea talks to Mary, who is apparently in medio posita marmore ('within the marble tomb', pp. 122-3), so perhaps this is a rather grander structure: for example, it could be a movable Easter sepulchre, formed, tent-like, from wooden poles with a cover, of a sort commonly found in late medieval churches. ${ }^{26}$ In any case, Mary is still clinging to the stone, so presumably is still outside the tomb's burial chamber, and she refuses to let go of the prop that she believes is significant because it is occupied, because it contains something hidden - albeit a dead body. Her friends convince her to return home to collect spices with which, in the morning, they will anoint the body: Myrrham, costum, spicaeque ('Myrrh, aloes, spikenard', pp. 130-1).

There are no explicit stage directions in Grimald's script as it survives, but the Argument of Act III tells us that the Marys return to the tomb cum emptis noctu odoribus ('bringing the perfumes that Mary had bought by night', p. 148). Medieval iconography identifies the Marys on the way to the tomb by the jars they carry, and it is likely that in the dramatic tradition ecclesiastical objects such as thuribles were used. ${ }^{27}$ In Grimald's play, Mary Magdalene cautions the other women, as they arrive at the tomb: Vos facitote, e gremijs ne quid odorum excidat ('take care that no perfume fall from your bosoms', pp. 158-9): the phrase, curiously, perhaps, redolent of erotic poetry, implies literally that the women carry the jars tucked into their costumes, so that they are perhaps concealed rather than displayed: at the same time it desolidifies the props by focusing 
attention on their contents, and the fragrance of their contents at that. Of course, if thuribles were used, the fragrance they scattered would have been that of incense rather than myrrh; however, a thurible that actually had smoking incense inside would have been too hot to carry tucked into a costume. In medieval-convent drama, the use of thuribles would have been a significant moment at which a female participant was permitted to touch an object usually reserved for male, clerical use: ${ }^{28}$ in Protestant drama, by contrast, if a thurible were used as a prop in this way, the effect could be at once to demystify ritual and to assert the primacy of the scriptural narrative which gives the prop a new significance, as a jar of ointment to anoint Christ.

The tomb contains another of the very few props that Grimald's play requires: linen cloths and a napkin. Though Mary Magdalene declares that there is nothing left in the tomb - nihil hic relinquitur (p. 158) - John later notes that there is nil, nisi linteamina ('nothing but the linen clothes', p. 160), and Peter explains their significance - Christ's body was once wrapped in them: ecce uestem linteam, En qua caput inuoluebatur, calanticam (p. 160). Medieval Catholic liturgical performances of the Visitatio Sepulchri present a very similar scene, and then invite participants to reverence the sudarium, the empty head-cloth, to emphasise its reliquary power; ${ }^{29}$ by contrast, Grimald's negating descriptions (nihil, nil) seem to deny significance to the material objects themselves, the emptiness of which requires interpretation, not reverence. In a sense, they were once costumes, but now they have become props because they are separated from the actor's body but are still on stage, deanimated and requiring a new interpretation as props. John offers that interpretation, and it depends on a choice between two narratives: either Christ's body has been stolen, or he has come to life. But, as John notes, if someone had stolen the body, they would not have placed the grave-cloths in order but would have taken them with the body. The grave-cloths signify because they are empty, but their continuing presence on stage as props points the disciples and the audience to a narrative that has not occupied the space and time of the performance, and that indeed requires a sense of divine, rather than human, space and time - the Resurrection of Christ's body.

The tomb has earlier been sealed by Caiaphas and Annas with a sigillum, or seal. In the Vulgate, the watch is set signantes lapidem, 'marking the stone', ${ }^{30}$ and this phrase was interpreted in medieval commentaries and later translations as 'sealing the stone'. ${ }^{31}$ What 
exactly does this imply? In Grimald, the sigillum has been given to Annas by Pilate, who is to use it to close up the tomb - haec sigillum, quo hunc locus obsignem dedit (p. 138). That it could be thus given suggests that it is not a device for materially sealing up the tomb but is rather a wax seal on a letter, a device that symbolically seals up the tomb by placing Pilate's authority on the order that it should be unopened. It is again a prop that resists its own materiality, here because its materiality would clearly be inadequate to the task of literally preventing entry.

Four soldiers are set to guard the tomb. These soldiers are the boasting but ineffective miles gloriosus type of Latin comedy. Thus when Jesus is miraculously raised from the dead, they are easily bribed by Caiaphas (at the inspiration of Alecto, who comes up from Hell) into saying instead that the body has been stolen. Caiaphas offers the soldiers a purse filled with silver - what Caiaphas describes as intus latet, 'what lies hidden within'. When the women return to the tomb and find it empty, and the stone rolled away, Cleophas declares, quid sibi tumulus inanis uelit, छ pate / Factum claustrum coniectura non adsequor ('what the empty tomb and the open door mean I do not understand', pp. 158-9). This is Act III scene iii, at the heart of the play. The rest of the play will show us the disciples learning how to interpret the empty prop, the significance of which is precisely the emptiness that points to meaning elsewhere - the risen Christ. What is or is not inside - that is the question.

In Archipropheta coins feature again as one of the few props, and again they are associated with folly: the fool Gelasimus offers a denarius and an obolus to the Syrian girl in exchange for a kiss (p. 262). Once again there are spices, used in Herod's sacred ceremonies: the Chorus declare that they return from these ceremonies carrying galbanum, myrrh, and frankincense for the temple, as well as other objects used in sacred rites (p. 312); perhaps, like the jars carried by the Marys, these might have been ecclesiastical objects such as thuribles, in which case their 'real-life' use as objects enriches their theatrical significance as props. Perfumes also feature, however, in a more profane moment, enhancing the charms of Tryphera as she prepares for the seductive dance by which she will bring about the death of John the Baptist. The finishing touch to her toilette is again perfume: En fragrantes accipe Odores (p. 316), her mother enjoins. This scene is exceptionally heavy on props, although they may also be interpreted as costumes: when Tryphera is dressing to dance before Herod, Herodias describes in 
great detail the jewels with which she adorns herself and Tryphera. She commands the Syrian girl to bring ring-cases, jewels, sandals, and all the rest of her ornaments, and then admires each ornament in turn, both for its appearance and for its supposed lapidary power:

Gerenti habe tutamen fidum jaspidem,

In isthoc orbe complicatum argenteo.

Hic Eliotropia est errare nescia.

Clarus hic Berillus est for a sexangula.

Hic uim uerbis addens Smaragdus clauditur.

Tibi ecce Magnetem, qui perficiet labris

In istis ut sedeat Suadela, et Gratia. (pp. 312-13)

(Now take the jasper set in this silver circle, a faithful guard to the wearer. Here a striped jasper, which prevents its wearer from wandering. This shining beryl is six-angled in shape. Here is enclosed an emerald, which gives power to one's words. See, here is a lodestone for you, which shall make persuasion and grace sit upon those lips.)

Here is a very particular approach to the materiality of props; Herodias simply asserts their talismanic power. Gems, of course, do have real physical properties - they can be striped or six-sided, and they can sparkle and adorn. Yet the idea that they can also have supernatural power, that they can make the wearer persuasive in speech, for example, is a superstition that would have been anathema to Reforming thinkers. Herodias's misuse of the material, her effort to give supernatural significance to the purely physical, is a certain signal to Grimald's audience of her doctrinal error.

Archipropheta, inevitably, reaches its climax with the beheading of John, and the presentation of the head at Herod's banquet. Ecce caput, the Chorus of Herod's men exhort (p. 334). The Syrian Girl responds with a quotation from the Aeneid: Non ista poscit hoc tempus spectacula ('the time demands no such sight as this', pp. 334-5): though this might at the most literal level mean simply that a severed head is not an appropriate prop at a banquet, the quotation almost comically reminds us that props should appear at the appropriate time and place. ${ }^{32}$ Herodias argues that John deserved his punishment, but her words seem lost in the visceral response of other characters to the sight of a severed head. The prop is, again, egregious; it does not fit the scene, and it does not belong at the king's banqueting table - Sancti ora uiri mersa cruore, / Ensa nefando caput ablatum, / Medios inter gerit Horoäs / Regia mensa ('The head 
of the holy man, stained with blood, the head cut off by impious sword, is displayed on the king's table in the midst of great men!', pp. 346-7). The Chorus define the prop, and then explain the horror of its inappropriateness - the question here is no longer whether John was a traitor or whether his preaching was true, his life moral, although this has been the question troubling Herod for most of the play. Rather, the audience, with the Chorus, must simply interpret the head as a shocking sign of Herod's tyranny, revealed, with a sick comedy, perhaps, as the tyranny of a bad host with terrible table manners.

Finally, of course, if there is a head there must be a trunk. This John's Disciples claim from Herod, though, as Innogen knows, a headless body is also rather difficult to interpret. ${ }^{33}$ A headless body is even more empty than a severed head. The Disciples' question - Hunc now o sancte te aspicimus uates? ('Is this you that we look upon, O holy prophet?', pp. 356-7) - is, comically, perhaps not simply rhetorical. How do we interpret these empty props? Perhaps the very uncertainty that they teach is the healthy scepticism about objects that Protestant drama demands.

\section{Notes}

1 See L. R. Merrill (ed.), The Life and Poems of Nicholas Grimald (New Haven, C'T: Yale University Press, 1925). All references to Grimald's plays will be to this edition, and translations of Grimald's Latin are Merrill's.

2 Records of Early English Drama: Oxford lists the plays of Bale and Foxe as 'Extra-mural' Oxford plays: see John R. Elliott (ed.), Records of Early English Drama: Oxford, 2 vols (Toronto: University of Toronto Press, 2004), 2, pp. 853-5. Andreas Höfele's chapter is 'John Foxe, Christus Triumphans', in Thomas Betteridge and Greg Walker (eds), The Oxford Handbook of Tudor Drama (Oxford: Oxford University Press, 2012), pp. 123-43. On the possibility of Three Laws having been performed at Madgalen, see James McBain, 'Recycling Authority: John Bale at Magdalen?', Medieval English Theatre 36 (2014), pp. 24-47.

3 The division of history into three legal ages was a of course a religious commonplace, available, for example, from traditional Catholic authorities including Bede, and the fifteenth-century Speculum Sacerdotale: it was also available from Protestant sources, notably Tyndale's The Obedience of a Christian Man (1528).

4 See James McBain, 'Recycling Authority', pp. 24-47.

5 Citations from the edition of Three Laws in Greg Walker (ed.), Medieval Drama: An Anthology (Oxford: Blackwell, 2000), lines 109-10, 119-20. 
6 For discussion of possible ways of staging Three Laws, see Elisabeth Dutton, Maria Sachiko Cecire, and James McBain, 'Staging and Filming John Bale's Three Laws', Shakespeare Bulletin 32.1 (2014), pp. 65-84.

7 Höfele, 'John Foxe, Christus Triumphans', p. 129.

8 Höfele, 'John Foxe, Christus Triumphans', p. 130.

9 See the edition in Two Latin Comedies by Fohn Foxe the Martyrologist, ed. John Hazel Smith (Ithaca, NY: Cornell University Press, 1973).

10 For the suggestion that adaptations made to this speech might indicate a performance at Magdalen College, Oxford, see Daniel Blank, 'Performing Exile: John Foxe's Christus Triumphans at Magdalen College, Oxford', Renaissance Studies 30:4 (2016), pp. 584-601.

11 Thomas Kirchmeyer's violently anti-Catholic Pammachius, Foxe's source for Christus Triumphans, has only four acts instead of five because, the Epilogue says, 'the Son of God will come and provide his own catastrophe'. Bale translated Kirchmeyer's Latin play into English. Howard B. Norland argues that Foxe's play displays violent Apocalypticism because it was written in the reign of Mary: 'John Foxe's Apocalyptic Comedy, Christus Triumphans', in Philip Ford and Andrew Taylor (eds), The Early Modern Cultures of Neo-Latin Drama (Leuven: University of Leuven Press, 2013), pp. 75-84, esp. p. 78.

12 See Elisabeth Dutton, 'Secular Medieval Drama', in Elaine Treharne and Greg Walker (eds), The Oxford Handbook to Medieval Literature (Oxford: Oxford University Press, 2010), pp. 384-94.

13 See Elisabeth Dutton and Stephanie Allen, 'Seeing and Recognizing in the Sacred and New: The Latin Scriptural Plays of Nicholas Grimald', in Peter Happé and Wim Hüsken (eds), Staging Scripture: Biblical Drama 1350-1600 (Leiden: Brill, 2016), pp. 204-34.

14 See also Chapter 10 in this volume: Hannibal Hamlin comments that all prophecy is a form of anachronism, and John the Baptist is the Arch-prophet.

15 Tiffany Stern's keynote speech at the conference 'Digitizing the Stage: Rethinking the Early Modern Theatre Archive', University of Oxford, July 2017.

16 Here cited from the 1560 edition of the Geneva Bible: The Geneva Bible: the Bible of the Protestant Reformation (Peabody, MA: Hendrickson, 2007).

17 St Augustine, City of God, trans. Henry Bettenson, intro. G. R. Evans (London: Penguin Classics, 2003). The City of God is 'the Jerusalem which is eternal in the heavens' (p. 939); the enemy of Jerusalem is 'Babylon, the City of the Devil, whose name means "confusion"' ( $p$. 747).

18 Andrew Sofer, The Stage Life of Props (Ann Arbor: University of Michigan Press, 1998), p. 62.

19 For a detailed exploration of theories about the relationships between temporality and the material object, see Jonathan Gil Harris, Untimely 
Matter in the Time of Shakespeare (Philadelphia: University of Pennsylvania Press, 2010).

20 See O. B. Hardison, Christian Rite and Christian Drama in the Middle Ages: Essays on the Original and Early History of Modern Drama (Baltimore, MD: Johns Hopkins University Press, 1965), pp. 37-79; Lawrence Clopper, Drama, Play, and Game: English Festive Culture in the Medieval and Early Modern Period (Chicago, IL: University of Chicago Press, 2001). For a recent discussion of the vexed question of the relationship between liturgy and drama, see Michael Norton, Liturgical Drama and the Reimagining of Medieval Theater (Kalamazoo, MI: Medieval Institute Publications, 2017).

21 Bruce Holsinger, 'Liturgy', in Paul Strohm (ed.), Middle English (Oxford: Oxford University Press, 2007), pp. 295-314, at p. 298.

22 Sofer, Stage Life of Props, pp. 50-1.

23 Charlotte Scott, Shakespeare and the Idea of the Book (Oxford: Oxford University Press, 2007), p. 10.

24 Philip Grierson, Catalogue of the Byzantine Coins in the Dumbarton Oaks Collection and in the Whittemore Collection (Cambridge, MA: Harvard University Press, 1999), vol. 5, part 1, p. 89.

25 Höfele, 'John Foxe, Christus Triumphans', p. 136.

26 These are described in Eamonn Duffy, The Stripping of the Altars: Traditional Religion in England c.1400-c.1580 (New Haven, CT: Yale University Press, 1992), p. 31. It is frustrating that we do not know where, in Brasenose College, this play was performed, but it is unlikely to have been the chapel, which at the time was very small and apparently lacked any permanent stone sepulchre: see J. M. Crook, Brasenose: The Biography of an Oxford College (Oxford: Oxford University Press, 2008). Crook writes that 'Even allowing for the diminutive size of the college in those early days, this first chapel can never have been commodious ... . It was a tiny sanctuary' (p. 19), and that it was 'little more than the upper chamber in a house of the early days of Christianity' (p. 14).

27 See M. A. Katritzky, 'Lucas van Leyden's “Toothdrawer”, 1523: Passion Play Merchant Scenes and the Religious Origins of Quack Depictions', in Birgit Ulrike Münch and Jürgen Müller (eds), Peiraikos' Erbe: Die Genese der Genremalerei 1450-1550, Trierer Beiträge zu den historischen Kulturwissenschaften 14 (Wiesbaden: Reichert, 2015), pp. 125-47.

28 For a discussion of the possible effects of the use of thuribles in performance, see Olivia Robinson and Elisabeth Dutton, 'Drama, Performance and Touch in the Medieval Convent and Beyond', in David Carillo-Rangel, Delfi I Nieto-Isabel, and Pablo Acosta García (eds), Touching, Devotional Practice and Visionary Experience in the Late Middle Ages (New York: Palgrave Macmillan, 2019), pp. 43-68.

29 For example, the Ludus Paschalis from the Abbey of Origny Ste Benoite indicates that the Apostles present the sudarium to all present, and the three Marys then kneel and kiss the sudarium. 
30 Matthew 27:66. Jerome, Biblia Sacra Vulgata, ed. Robertus Weber and Roger Gryson, 4th rev. edn (Peabody, MA: Hendrickson, 2007).

31 See Peter Meredith, 'The Sealing of the Tomb: N. Town and its Context', Medieval English Theatre 29 (2007), pp. 75-88.

32 These are the words of the Sibyl to Aeneas when he contemplates wall paintings showing the history of Troy. See Virgil's Aeneid, VI.37.

33 In William Shakespeare's Cymbeline, Innogen mistakes the headless trunk of her attacker Cloten for the body of her husband, Posthumous, in one of the most famously problematic cases of mistaken identity in theatrical history. 